O R I G I N A L

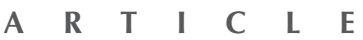

\section{Jacqueline PW Chung 鍾佩樺 \\ Christopher J Haines 韓英士 Grace WS Kong 江穎珊}

\title{
Sperm cryopreservation for Chinese male cancer patients: a 17-year retrospective analysis in an assisted reproductive unit in Hong Kong
}

Objective To review sperm cryopreservation usage rates, corresponding reproductive outcomes, and the current situation in our locality.

Design Retrospective case series.

Setting Assisted Reproductive Technology Unit of the Department of Obstetrics and Gynaecology, Prince of Wales Hospital and the Chinese University of Hong Kong.

Participants There were 130 Chinese male patients who underwent sperm cryopreservation before proceeding to gonadotoxic treatment from January 1995 to January 2012.

Main outcome measures Demographic data, type of cancers and treatments, semen analysis, and reproductive outcomes.

Results The median patient age was 27 (range, 15-43) years. Most (85\%) were single at the time of referral. Over half of the patients (51\%) had testicular cancer. Five patients declined sperm cryopreservation after counselling. Among the remaining 125 men, 122 men were able to produce sperm by masturbation but 12 were found to have azoospermia, leaving a total of 110 who proceeded to semen cryopreservation. There were no significant differences in semen parameters between different cancer types. After gonadotoxic treatment, in up to $32 \%(n=11 / 34)$ of the patients, semen analysis yielded deterioration; four patients had azoospermia. Four patients $(4 \%, n=4 / 110)$ came back to use their thawed semen for in-vitro fertilisation (intracytoplasmic sperm injection), which resulted in three successful singleton pregnancies.

Conclusion Sperm cryopreservation is a simple and effective way of preserving the fertility potential of male patients undergoing gonadotoxic treatment. This procedure is underutilised and deserves increased awareness by all possible means.

Key words Cryopreservation; Fertility preservation; Infertility, male; Sperm banks; Testicular

neoplasms

Hong Kong Med J 2013;19:525-30 DOI: $10.12809 / \mathrm{hkmj} 134055$

Department of Obstetrics and Gynaecology, The Chinese University of Hong Kong, Prince of Wales Hospital, Shatin, Hong Kong

JPW Chung, MB, ChB, FHKAM (Obstetrics and Gynaecology)

CJ Haines, MB, BS, FHKAM (Obstetrics an Gynaecology)

GWS Kong, MB, ChB, FHKAM (Obstetrics and Gynaecology)

Correspondence to: Dr JPW Chung Email: jacquelinechung@cuhk.edu.hk
New knowledge added by this study

- Sperm cryopreservation for male cancer patients is underutilised in the Hong Kong population.

- Approximately $85 \%$ of the referred patients had successful sperm cryopreservation, demonstrating the feasibility of this procedure.

- In our study, up to $32 \%(n=11 / 34)$ of the patients had significantly worse semen analysis findings (including four who suffered from azoospermia) after their gonadotoxic treatment. Thus, sperm cryopreservation is an invaluable tool for preserving the progenitive potential of male patients undergoing gonadotoxic treatment.

\section{Implications for clinical practice or policy}

- Every effort should be made to refer these patients for sperm cryopreservation before proceeding to their gonadotoxic treatment, even if their sperm quality is suboptimal.

- Clinical policies are required to increase awareness about sperm cryopreservation knowledge in patients and physicians.

\section{Introduction}

The number of young men in the reproductive age bracket with cancers who survive has increased dramatically over the last few years, largely due to improvements in diagnostic and treatment modalities. ${ }^{1-4}$ Testicular cancer and Hodgkin's disease are the 


\section{華籍男性癌症患者的精子冷凍保存技術：回顧 分析香港一所輔助生殖部門17年間的病例}

\author{
目的 找出精子冷凍保存技術的使用率和相應的生殖結果, \\ 並探討本港使用這技術的現況。 \\ 設計 回顧病例系列。 \\ 安排 香港中文大學及威爾斯親王醫院婦產科學系轄下的輔 \\ 助生殖技術部門。 \\ 參與者 1995 年1月至2012年1月期間在接受癌症治療前進行 \\ 精子冷凍保存的 130 名華籍男性。 \\ 主要結果測量 人口學數據、癌症類型及治療、精液分析和生殖結 \\ 果。 \\ 結果 患者年齡中位數為27歲（介乎15-43歲），他們大多 \\ 數 $(85 \%)$ 在接受診治時仍為單身。超過半數患者 \\ ( $51 \%$ ) 有睪丸癌。5名病人在接受輔導後決定不進 \\ 行精子冷凍保存。餘下的 125 人中, 122 例藉自慰獲得 \\ 精子, 當中 12 例為無精子症患者, 最後共 110 人進行 \\ 精液冷凍法。不同類型的癌症患者的精液參數並無顯 \\ 著差異。接受癌症治療後, $32 \%(n=11 / 34)$ 患者的 \\ 精液分析結果顯示精液參數變壞; 4 例證實為無精子 \\ 症。另 4 例 ( $4 \%, n=4 / 110)$ 其後使用他們的解凍精 \\ 液進行體外受精（胞漿內單精子注射）, 結果有三個 \\ 單胎娃娠的成功個案。 \\ 結論 為接受癌症治療前的男性患者進行精子冷凍保存以保 \\ 存其生育能力是一個簡單有效的方法。此技術未被充 \\ 分利用, 應盡力提高有關的意識。
}

two most common malignancies among young males in this age-group. Advances in chemotherapy have greatly improved the cure and survival rates of these patients. The 5-year survival for testicular cancer is $95 \%$, while for Hodgkin's disease it is up to $80 \% .^{1-5}$ The majority of these cancer patients are diagnosed when they are still young, most being single and/or not having completed their families. In this group of patients, male infertility is therefore still a major concern, since the treatment necessary (chemotherapy or radiotherapy) may adversely affect their fertility. Although the harmful effects of chemotherapy or radiotherapy on spermatogenesis largely depend on the type of treatment, its dosage and its duration, at present it is still not possible to predict spermatogenesis recovery after treatment in specific patients..$^{1,2}$

With the increasing availability of assisted reproductive technology (ART), many of these patients and their clinicians are seeking to preserve their fertility potential by sperm cryopreservation before embarking on gonadotoxic therapies. Application of intracytoplasmic sperm injection (ICSI) also allows many affected patients with poor semen characteristics or low sperm survival after thawing to father their own genetic children in the future. $^{2}$

Sperm cryopreservation is a simple and effective way of preserving their fertility potential and should be recommended for all men undergoing potentially sterilising treatments. ${ }^{1-4}$ However, the rate of sperm cryopreservation under these circumstances is low, especially in the Chinese population, ${ }^{5}$ Moreover, data currently available about sperm cryopreservation in this population are limited. We therefore opted to perform a retrospective review of sperm cryopreservation in the Assisted Reproductive Technology Unit to explore the current situation in our locality.

\section{Methods}

Since 1995, the Prince of Wales Hospital (affiliated with the Chinese University of Hong Kong) has been providing sperm cryopreservation for male patients undergoing gonadotoxic treatment for malignant cancers that could jeopardise their fertility potential. This was therefore a retrospective study evaluating all Chinese male patients having sperm cryopreservation before proceeding to gonadotoxic treatment in our infertility centre from January 1995 to January 2012.

Before signing a written consent for cryopreservation, all relevant patients were counselled by an infertility specialist and fully informed about the procedure, including the process entailed, costs, future use, and storage duration. All the patients were screened for sexually transmitted diseases, including human immunodeficiency virus, and hepatitis $B$ and $C$ viruses. The maximum storage period was until the patient reached an age of 55 years or for 10 years, whichever was longer. Moreover, it was stipulated that the stored gametes were only used for a married couple, and only when the disease was in remission. Moreover, no posthumous conception would be allowed. The aforementioned stipulations were in line with the Code of Practice formulated by the Council on Human Reproductive Technology of Hong Kong since $2007 .{ }^{6}$ In our centre, consent was renewed every 2 years.

Patients were asked to submit semen samples for cryopreservation and semen analysis by masturbation, which was performed according to the World Health Organization guidelines valid at that time. Sperm cryopreservation was performed according to a standardised protocol in our hospital, and only on semen samples containing motile spermatozoa. If no motile sperms were detected, the finding was discussed with the patient and the sample was not cryopreserved. The semen samples were mixed with an equal volume of commercially 
available cryoprotectant. After thorough mixing and aliquoting into cryopreservation vials, the samples were cooled by suspension in vapour-phase nitrogen at a rate of approximately $-10^{\circ} \mathrm{C}$ per minute for 30 minutes and plunged into liquid nitrogen for storage.

The medical notes of these patients were reviewed and demographic and other data were logged. Such data included the age at diagnosis and referral, type of cancer and treatment, pre- and post-sperm cryopreservation semen analysis results, length of semen cryopreservation, results and types of ART tried. The reasons for discarding any semen samples were also explored.

\section{Statistical analyses}

The Statistical Package for the Social Sciences (Windows version 18.0; SPSS Inc, Chicago [IL], US) was used for data entry and analysis. The Chi squared test was used for categorical data and Student's $t$ test for continuous variables. Any $\mathrm{P}<0.05$ was considered statistically significant.

\section{Results}

A total of 130 male Chinese patients were referred for sperm cryopreservation in our hospital during the period January 1995 to January 2012. The mean waiting time for first consultation was 4 days with a median of 2 days. Most of the patients $(94 \%, n=122)$ were referred from other departments in the public sector, while the remainder were referred from the private sector.

Table 1 shows the demographic and clinical characteristics of the patients. Of the 130 patients, five did not undergo sperm cryopreservation after counselling by our specialist (3 proceeded to gonadotoxic treatment immediately and 2 declined such therapy due to their poor prognosis). Of the remaining 125 men, 122 were able to produce semen by masturbation but three did not. Regarding the 122 patients who produced semen, 10\% (12/122) were diagnosed to have azoospermia based on semen analysis: seven had testicular cancer and had undergone unilateral orchidectomy, three had untreated leukaemia, and two had Hodgkin's disease with prior chemotherapy (both had received the ABVD regimen-adriamycin, bleomycin, vinblastine and dacarbazine). Thus, there were 110 men who proceeded to sperm cryopreservation.

Throughout the study period, 176 samples were cryopreserved, ranging from 1 to 5 samples per patient. Excluding the 12 samples that were azoospermic, there were 164 samples available for detailed analysis. The median semen parameters for the cryopreserved sperm were as follows: volume 2.5 (range, 0-3) $\mathrm{mL}$, sperm count 35 (range, 0-170) million/mL,
TABLE I. Demographic and clinical characteristics of the patients referred for sperm cryopreservation $(n=130)$

\begin{tabular}{|c|c|}
\hline $\begin{array}{l}\text { Demographics and clinical } \\
\text { characteristics }\end{array}$ & $\begin{array}{l}\text { No. (\%) of patients, } \\
\text { or median (range) }\end{array}$ \\
\hline Age at diagnosis (years) & $27(12-43)$ \\
\hline Age at referral (years) & $27(15-43)$ \\
\hline \multicolumn{2}{|l|}{ Marital status } \\
\hline Single & $110(85 \%)$ \\
\hline Married & $20(15 \%)$ \\
\hline Without children & 16 \\
\hline With children & 4 \\
\hline \multicolumn{2}{|l|}{ Diagnosis } \\
\hline Testicular cancer & $66(51 \%)$ \\
\hline Haematological malignancy & $28(22 \%)$ \\
\hline Non-Hodgkin's disease & 14 \\
\hline Hodgkin's disease & 6 \\
\hline Others & 8 \\
\hline Gastro-intestinal malignancy & $9(7 \%)$ \\
\hline Musculoskeletal malignancy & $9(7 \%)$ \\
\hline Neurological malignancy & $5(4 \%)$ \\
\hline Nasopharyngeal malignancy & $5(4 \%)$ \\
\hline Others & $8(6 \%)$ \\
\hline \multicolumn{2}{|l|}{ Treatment before cryopreservation } \\
\hline None & $49(38 \%)$ \\
\hline Operation & $77(59 \%)$ \\
\hline Chemotherapy & $3(2 \%)$ \\
\hline Immunotherapy & $1(1 \%)$ \\
\hline
\end{tabular}

and motility $36 \%$ (range, $0-70 \%$ ). There were no significant differences in semen parameters in patients with different cancer types.

Cryopreserved samples of 41 patients were discarded during the time of the study. They included 23 recovered patients with restored spermatogenesis according to semen analysis, 15 who died before using their sperm, two who declined to continue storing their sperm due to social problems, and one following a spontaneous pregnancy in his partner. Among the 23 recovered patients with normal semen analysis, 13 had undergone chemotherapy, six had had radiotherapy, and four had had both treatments. The mean time span between treatment and sperm disposal was 4 (range, 3-13; median, 4) years, while the mean time span from cryopreservation to death $(n=15)$ was 3 (range, 1-13; median, 2) years. Eleven patients $(32 \%, n=11 / 34)$ with normal semen analysis before treatment came back to consider disposal of their sperms after their treatment. However, they changed their minds as they were found to have significantly inferior semen when it was re-analysed; seven of them had counts of $<15 \mathrm{million} / \mathrm{mL}$ and four 
patients became azoospermic. The details of these patients are listed in Table 2.

Four patients came back to use their cryopreserved sperm for in-vitro fertilisation (IVF) with ICSI and in three of them successful singleton live births were achieved. The mean time from cryopreservation to usage was 5 years. Details of these cases are listed in Table 3.

\section{Discussion}

With the improved survival of male cancer patients, semen by masturbation and had motile sperm for many want to father their own child after remission. cryopreservation, demonstrating the feasibility of

TABLE 2. Details of patients with abnormal semen analysis or azoospermia after treatment

\begin{tabular}{|c|c|c|c|c|c|c|c|c|c|c|}
\hline \multirow{2}{*}{$\begin{array}{l}\text { Patient } \\
\text { No. }\end{array}$} & \multirow{2}{*}{$\begin{array}{c}\text { Age } \\
\text { (years) }\end{array}$} & \multirow[t]{2}{*}{ Cancer type } & \multirow[t]{2}{*}{ Treatment } & \multicolumn{3}{|c|}{ Pre-treatment semen analysis } & \multirow{2}{*}{$\begin{array}{l}\text { Duration } \\
\text { from } \\
\text { cryopre- } \\
\text { servation }\end{array}$} & \multicolumn{3}{|c|}{ Post-treatment semen analysis } \\
\hline & & & & $\begin{array}{l}\text { Volume } \\
\text { (mL) }\end{array}$ & $\begin{array}{l}\text { Count } \\
\left(x 10^{6}\right)\end{array}$ & Motility (\%) & & $\begin{array}{l}\text { Volume } \\
\text { (mL) }\end{array}$ & $\begin{array}{l}\text { Count } \\
\left(x 10^{6}\right)\end{array}$ & Motility (\%) \\
\hline 1 & 20 & $\mathrm{CNS}^{*}$ tumour & $\begin{array}{l}\text { Chemotherapy and } \\
\text { radiotherapy }\end{array}$ & 2.2 & 110 & 75 & 5 & 1.8 & 8 & 20 \\
\hline 2 & 23 & $\begin{array}{l}\text { Hodgkin's } \\
\text { lymphoma }\end{array}$ & $\begin{array}{l}\text { Chemotherapy and } \\
\text { radiotherapy }\end{array}$ & 1.2 & 88 & 65 & 6 & 2.5 & \multicolumn{2}{|c|}{ Azoospermia } \\
\hline 3 & 27 & $\begin{array}{l}\text { Hodgkin's } \\
\text { lymphoma }\end{array}$ & Chemotherapy & 2 & 67 & 40 & 10 & 2.3 & Very few & $\begin{array}{l}\text { 2-3 Motile } \\
\text { per sperms } \\
\text { per slide }\end{array}$ \\
\hline 4 & 26 & $\begin{array}{l}\text { Nasopharyngeal } \\
\text { tumour }\end{array}$ & $\begin{array}{l}\text { Chemotherapy and } \\
\text { radiotherapy }\end{array}$ & 2.5 & 80 & 50 & 8 & 2.5 & 5 & 10 \\
\hline 5 & 32 & $\begin{array}{l}\text { Non-Hodgkin's } \\
\text { lymphoma }\end{array}$ & Chemotherapy & 1.5 & 56 & 55 & 5 & 1.2 & 6 & 42 \\
\hline 6 & 20 & Testicular tumour & Chemotherapy & 3.6 & 7 & 50 & 6 & 3.6 & 8 & 56 \\
\hline 7 & 21 & Testicular tumour & Chemotherapy & 2.3 & 35 & 30 & 7 & 2.5 & 5 & 32 \\
\hline 8 & 23 & Testicular tumour & Radiotherapy & 2 & 15 & $\begin{array}{l}\text { 2-3 Motile } \\
\text { sperms per } \\
\text { slide }\end{array}$ & 9 & 1.5 & \multicolumn{2}{|c|}{ Azoospermia } \\
\hline 9 & 30 & Testicular tumour & Radiotherapy & 2.5 & 8 & 40 & 3 & 2.2 & \multicolumn{2}{|c|}{ Azoospermia } \\
\hline 10 & 32 & Testicular tumour & Chemotherapy & 3 & 10 & 50 & 4 & 2.5 & \multicolumn{2}{|c|}{ Azoospermia } \\
\hline 11 & 39 & Testicular tumour & Chemotherapy & 2.8 & 45 & 35 & 4 & 1 & $<1$ & $\begin{array}{l}\text { 2-3 Motile } \\
\text { sperms per } \\
\text { slide }\end{array}$ \\
\hline
\end{tabular}

* CNS denotes central nervous system

TABLE 3. Details of men using cryopreserved sperm and their reproductive outcomes

\begin{tabular}{|c|c|c|c|c|c|}
\hline $\begin{array}{l}\text { Age } \\
\text { (years) }\end{array}$ & Pathology and treatment & $\begin{array}{l}\text { Duration } \\
\text { from } \\
\text { freezing } \\
\text { (years) }\end{array}$ & $\begin{array}{c}\text { Pre- and post-treatment semen } \\
\text { analysis }\end{array}$ & $\begin{array}{c}\text { Age } \\
\text { (years) of } \\
\text { female } \\
\text { partner }\end{array}$ & Reproductive outcome \\
\hline 23 & $\begin{array}{l}\text { Stage I right testicular seminoma with } \\
\text { orchidectomy followed by radiotherapy }\end{array}$ & 9 & $\begin{array}{l}\text { (Pre) Count: } 15 \text { million/mL, motility: } 2-3 \\
\text { motile sperms per slide } \\
\text { (Post) Azoospermia }\end{array}$ & 30 & Singleton live birth \\
\hline 30 & $\begin{array}{l}\text { Stage I right testicular seminoma with } \\
\text { orchidectomy followed by radiotherapy }\end{array}$ & 3 & $\begin{array}{l}\text { (Pre) Count: } 8 \text { million/mL, motility: } 40 \% \\
\text { (Post) Azoospermia }\end{array}$ & 35 & Singleton live birth \\
\hline 32 & $\begin{array}{l}\text { Stage I germ cell tumour with left } \\
\text { orchidectomy followed by chemotherapy }\end{array}$ & 4 & $\begin{array}{l}\text { (Pre) Count: } 10 \text { million/mL, motility: } 50 \% \\
\text { (Post) Azoospermia }\end{array}$ & 32 & Biochemical pregnancy* \\
\hline 39 & $\begin{array}{l}\text { Stage I seminoma with left orchidectomy } \\
\text { followed by chemotherapy }\end{array}$ & 4 & $\begin{array}{l}\text { (Pre) Count: } 45 \text { million } / \mathrm{mL} \text {, motility: } 35 \% \\
\text { (Post) Count: }<1 \text { million/mL, motility: } 2-3 \\
\text { motile sperms per slide }\end{array}$ & 33 & Singleton live birth \\
\hline
\end{tabular}

* Pregnancy confirmed biochemically but not located on ultrasound scan 
strategy.

After being diagnosed, every effort should be made to refer these patients for sperm cryopreservation before proceeding to treatment. In our study, up to $10 \%(n=12 / 122)$ of them were already azoospermic before sperm cryopreservation and cancer treatment, and about $32 \% \quad(n=11 / 34)$ endured deterioration of their semen when it was reanalysed post-treatment. This concurs with previous studies in which a significant percentage of patients diagnosed with cancer may in fact be azoospermic before gonadotoxic treatment, presumably due to spermatogenic depression related to the cancer and that a proportion of them also become azoospermic after gonadotoxic treatment. ${ }^{7}$ Since it is still not possible to predict which group of patients will have recovery of spermatogenesis after treatment, timely referral for sperm cryopreservation is of paramount importance.

The number of male patients being referred for sperm cryopreservation has been progressively increasing in the last few years. In our unit, the number has risen 10 -fold from 2 cases per year in 1995 to 20 cases per year in 2005. However, awareness of this procedure is still insufficient. Over the past 17 years, the majority of our patients were referred by urologists, and remarkably over this period only 66 patients with testicular cancers were referred to us. This suggests a high degree of underutilisation of our service. Only a small portion of those suffering from haematological or other malignancies who receive gonadotoxic treatment were referred for sperm cryopreservation. In previous studies, this has been attributed to the lack of knowledge about ART and sperm cryopreservation. ${ }^{8,9}$ In a future study, we hope to elucidate the rationale and referral selection criteria used by physicians and oncologists with respect to sperm cryopreservation in male cancer patients.

We believe that financial considerations may also be a factor affecting sperm cryopreservation. In our unit, since July 2012 sperm cryopreservation has been carried out as a private service and costs around HK\$4800 for every 2 years over the initial 4 years and HK\$9600 for every 2 years thereafter. This compares to HK\$2000 for every 2 years during the 1990s. This may be a heavy burden for low-income patients who already need to pay for their cancer treatments. Thus, for patients without existing offspring, the government should consider offering financial support for semen cryopreservation.

Moreover, many may not be aware of the improved success rate and ART outcomes from sperm cryopreservation. The literature records at least two successful live births by intrauterine insemination with sperm cryopreserved up to 28 years, exemplifying the success of this service. ${ }^{10}$ Furthermore, the success rates of IVF and ICSI treatments using cryopreserved semen are now comparable to those of using fresh semen. ${ }^{11,12}$ In our study, three out of four men who came back to use their cryopreserved sperm were able to achieve a successful pregnancy, even in that one patient who only had a few motile sperms per slide. With the advance of ICSI treatment, male patients should be made aware that only a few motile spermatozoa are required to achieve fatherhood, and thus they should be encouraged to consider sperm cryopreservation even if their sperm quality is suboptimal before gonadotoxic treatment.

At the time of the study, only four men $4 \%$, $n=4 / 110$ ) returned to use their cryopreserved sperm for infertility treatment. This usage rate is considered to be low compared with those reported from other international oncology-infertility centres where they ranged from 6 to $39 \% .^{1-5,12,13}$ These men might never have fathered their own child had they not had cryopreserved sperm. The low usage rate in our series may have been due to the fact that many patients were still young and single at the time of sperm cryopreservation, and may not consider family planning until they are married. With the increasing trend towards late marriages in Hong Kong, family planning may be further delayed. In addition, many of these patients may still have been under surveillance for their disease during the study period and may not return until their condition is in remission or if they are certain about their long-term prognosis. Again, financial considerations and lack of awareness of the success of ART may be other factors affecting the usage. Nonetheless, we strongly believe that sperm cryopreservation should still be continued, even if only a few patients come back for treatment.

Survival from childhood malignancies in prepubertal boys is also improving due to improvements in diagnostic and treatment modalities. However, preserving fertility potential in such boys remains challenging. Sperm cryopreservation can nevertheless be performed in adolescents, if sperm can be collected by masturbation, penile vibrostimulation, or electroejaculation. ${ }^{14,15}$ In patients for whom sperm collection is not feasible, testicular tissue recovery and cryopreservation followed by subsequent spermatogonial stem cell transplantation may be an option but is still experimental at this stage. ${ }^{14-16}$

\section{Conclusion}

Sperm cryopreservation is considered an invaluable tool for preserving the progenitive potential of male patients undergoing gonadotoxic treatment. We hope this study can increase the awareness and confidence of the physicians and patients about sperm cryopreservation, so that timely referral can be made before gonadotoxic treatment. 


\section{References}

1. Lass A, Akagbosu F, Abusheikha N, et al. A programme of semen cryopreservation for patients with malignant disease in a tertiary infertility centre: lessons from 8 years' experience. Hum Reprod 1998;13:3256-61. cross ref

2. Meseguer M, Molina N, García-Velasco JA, Remohí J, Pellicer A, Garrido N. Sperm cryopreservation in oncological patients: a 14-year follow-up study. Fertil Steril 2006;85:640-5. cross ref

3. Schmidt KL, Larsen E, Bangsbøll S, Meinertz H, Carlsen $\mathrm{E}$, Andersen AN. Assisted reproduction in male cancer survivors: fertility treatment and outcome in 67 couples. Hum Reprod 2004;19:2806-10. cross ref

4. Fosså SD, Aass N, Molne K. Is routine pre-treatment cryopreservation of semen worthwhile in the management of patients with testicular cancer? Br J Urol 1989;64:5249. cross ref

5. Ping $\mathrm{P}$, Zhu $W B$, Zhang $X Z$, et al. Sperm banking for male reproductive preservation: a 6-year retrospective multi-centre study in China. Asian J Androl 2010;12:35662. cross ref

6. Council on Human Reproductive Technology. Code of Practice on Reproductive Technology and Embryo Research January 2013. Available from: http://www.chrt.org.hk/ english/publications/files/code.pdf. Accessed Jun 2013.

7. Ragni G, Arnoldi M, Somigliana E, Paffoni A, Brambilla ME, Restelli L. Reproductive prognosis in male patients with azoospermia at the time of cancer diagnosis. Fertil Steril 2005;83:1674-9. cross ref

8. Rabah DM, Wahdan IH, Merdawy A, Abourafe B, Arafa
MA. Oncologists' knowledge and practice towards sperm cryopreservation in Arabic communities. J Cancer Surviv 2010;4:279-83. cross ref

9. Mancini J, Rey D, Préau M, Malavolti L, Moatti JP. Infertility induced by cancer treatment: inappropriate or no information provided to majority of French survivors of cancer. Fertil Steril 2008;90:1616-25. cross ref

10. Feldschuh J, Brassel J, Durso N, Levine A. Successful sperm storage for 28 years. Fertil Steril 2005;84:1017. cross ref

11. Sanger WG, Olson JH, Sherman JK. Semen cryobanking for men with cancer-criteria change. Fertil Steril 1992;58:1024-7.

12. Borges E Jr, Rossi LM, Locambo de Freitas CV, et al. Fertilization and pregnancy outcome after intracytoplasmic injection with fresh or cryopreserved ejaculated spermatozoa. Fertil Steril 2007;87:316-20. cross ref

13. van Casteren NJ, van Santbrink EJ, van Inzen W, Romijn JC, Dohle GR. Use rate and assisted reproduction technologies outcome of cryopreserved semen from 629 cancer patients. Fertil Steril 2008;90:2245-50. cross ref

14. Holoch P, Wald M. Current options for preservation of fertility in the male. Fertil Steril 2011;96:286-90. cross ref

15. Tournaye H, Goossens E, Verheyen G, et al. Preserving the reproductive potential of men and boys with cancer: current concepts and future prospects. Hum Reprod Update 2004;10:525-32. cross ref

16. Goossens E, Van Saen D, Tournaye H. Spermatogonial stem cell preservation and transplantation: from research to clinic. Hum Reprod 2013;28:897-907. cross ref 